\title{
The early Quaker peace testimony and masculinity in England, 1660-1720
}

Shortly after his Restoration in 1660, Charles II received 'A Declaration from the harmless and innocent people of God, called Quakers' announcing their principles of seeking peace and the denial of '[a]ll bloody principles and practices', as well as 'outward wars and strife, and fightings with outward weapons, for any end, or under any pretense whatsoever’. ${ }^{1}$ The early Quaker peace testimony, represented by the 1660 'Declaration’, was closely related to refashioned Quaker masculinity after the Restoration. As Fox wrote in the 'Declaration', contrasting the dishonourable, unmanly nature of worldly men with the manly bravery of Quakers, 'It is not an honour, to manhood or nobility, to run upon harmless people, who lift not up a hand against them, with arms and weapons.' ${ }^{2}$ Such bold assertions were commented upon almost immediately; as the prophet and visionary defender of the Church of England Arise Evans responded, 'The Quakers give out forsooth, that they will not rebel nor fight, when indeed the last year, and all along the War, the Army was full of them. ${ }^{3}$ Although this was not entirely the case, the public declaration of Friends' rejection of war was a cornerstone of refashioned Quaker masculinity from the Restoration. Karen Harvey and Alexandra Shepard assert that most research into the history of masculinity has concentrated on dominant groups of men, whilst more work is needed on the range of different codes available to others, and as Shepard goes on to suggest, some men 'pursued alternative codes of manhood' ${ }^{4}$ which related to social status, but also to religious identity. ${ }^{5}$ Based on a consideration of the extent to which non-violent forms of control were used by male Friends, this analysis seeks to demonstrate the need to move from a simplistic binary notion of 'hegemonic' and 'subversive' early modern masculine identities, and to recognise the extent to which some groups, such as Quakers, sought to reject the worst excesses of gendered violence in the home and local community, in parallel to Puritans several decades earlier, but were most distinctive in their gendered rejection of violence enacted outside the community and its perpetrators. Through the use of a range of material demonstrating cultural constructions of masculinity, such as the records of Quaker meetings, spiritual journals and published declarations of faith, and drawing upon recent scholarship on gender and violence, this article offers insights into the first decades of one form of nonconformist masculinity, to draw out areas of similarity and difference in terms of gendered, lived experience between Friends and the 'world'.

Existing scholarship on early modern masculinity is a useful starting point from which to consider early Quaker attitudes to violence and, conversely, to behaviour considered acceptable for male Friends. Some years ago, feminist 
theologians called attention to 'the failure of religious traditions and scholarly reflections on religion to take into account the experiences of women', and this has been mirrored in recent years by parallel studies of men as a specific group, with masculinities 'as objects of study on a par with femininities' ${ }^{6}$ One of the key themes identified, power and its role in the shaping of male identities, highlights the anxiety inherent in masculinity, a theme common in both historical and sociological accounts. The philosopher Steve Smith, for example, has explored the paradox of a gender which is more powerful, yet in the very pursuit and maintenance of power becomes destructive to those who wield it. $^{7}$ Although early Friends 'preached a radical message on power and nonviolence', ${ }^{8}$ asserting the spiritual equality of all before God did not prevent them from maintaining gendered power structures through the separation of men's and women's meetings. We must ask, then, fundamental questions about 'the role of religion in supporting or resisting unstable masculine identities’ or rationalising unjust power relations between men and women. ${ }^{9}$ Historical studies considering ‘cultural constructions of masculinity and religious texts, institutions, and practices' are vitally important to this enterprise and this study attempts to offer some insights. ${ }^{10}$

Early Friends distinguished themselves from other groups in various ways, with implications for both male and female Friends. Their peace testimony, for example, led to their largely non-violent response to physical abuse. Friends' peace testimony has been described as 'a serious form of resistance', for alongside their refusal to serve in the armed forces, Friends also 'refused to subsidise acts of war in any sense', moral or financial, including more localised efforts to raise militia. ${ }^{11}$ Friends were also keen to maintain their individual and group credit in the community, and this was achieved by impeccable business practices, largely on the part of Quaker men. The encouragement of women preachers in the first decades of Quakerism also had implications for external perceptions of both female and male Friends. Although cultural attributes such as clothing were increasingly used in the late seventeenth-century metropolis to identify gentility, Friends used clothing to identify other Quakers rather than as a means to ascertain rank and breeding. Regardless of their social status, their spiritual status was equal. This, as well as their pacifism and the active role of women as prophets and preachers in the early movement, ${ }^{12}$ led to welldocumented criticism of Quakerism. Fear within the Friends of the accusation of effeminacy and of failing to support patriarchy, may have led in part to the maintenance, if not the original construction, of a system of separate men's and women's meetings. ${ }^{13}$ Antipathy to tavern culture, and the refusal to bear arms, potentially left Friends open to such criticisms, and all-male meetings may have provided a more civilised alternative to alehouse culture, and filled the cultural vacuum left by their rejection of tavern-going. Further, Friends' published accounts of sufferings, and 
Quaker journals, show a manipulation of gender roles, especially the formation and development of Quaker masculinity, in opposition to that of the world. Recently, scholars of early modern spiritual autobiographies have commented upon the anxious masculinity apparent - or absent - in the texts they analyse. Whether Quaker or Puritan, Michael Ditmore and Hilary Hinds, amongst others, note how religious belief might lend weight to gendered anxiety or alternatively, might remove it altogether. ${ }^{14}$ Whilst not every Quaker journal considered here offers the same degree of self-confidence identified by Hilary Hinds in that of George Fox, an insightful analysis of Quaker doctrine and self-representation to which I shall return, Such journals outline ways in which Quakers perceived themselves as differing from the world, reflecting self-fashioning at both individual and group levels and scholarly analyses of seventeenth- and eighteenth-century culture suggest a move, then, from a society divided by religion in the midseventeenth century, to a more secular society divided by cultural ideals a century later, and certainly Friends, alongside other religious groups, propounded respectable ideals of manhood in their published accounts.

A question arises, then, about how Friends maintained the respect of the world, although they claimed not to care for worldly honour. If Quakers would not defend themselves if they were attacked because they were Friends, their passive response could be understood as part of their sufferings. Davies has suggested that early pacifist Friends were in an alternative manner, both militaristic and aggressive, demonstrating 'Christ's meeting of blows with assertive patience.' Hinds, too, considers how Fox both before and after the Restoration depicted 'the insufficiency of his opponents' merely temporal power' in the face of God's power, which acted within Fox to refresh him after he received beatings. ${ }^{15}$ However, by the Restoration, Quakers had to a greater degree stepped outside the arena of worldly manhood, including aggression and violence. They still, though, proved their ability to control those within their ranks, women especially, through means in harmony with their peace testimony but effective enough to maintain God's patriarchal honour. ${ }^{16}$ Here it is useful to refer to Stuart Carroll's analysis of the historical relationship between the word violence, and related terms such as control, domination and authority, links which are not immediately apparent in modern English. ${ }^{17}$ Quaker men did not relinquish discipline and control, especially of women, as their minute books and the existence of the editorial committee suggest. Their techniques combined pacifistic but not passive responses to sufferings with a rejection of all forms of violence and may be understood with reference to Boulding's work on power and Smith's on masculinity and power. In addition, their social status, which gradually narrowed and meant by the end of the period considered, that most English Friends were of middling status, enabled them to maintain respect, especially post-Toleration. ${ }^{18}$ Closer ties to local elites may, then, have 
enabled them to influence the attitudes and behaviour of non-Quakers, and not merely to have become more like the majority.

A number of studies in seventeenth- and eighteenth-century cultural history have, more or less explicitly, considered masculinity, and the main strands of this work will be drawn out in order to assess to what degree existing scholarship may be applied to early Quakerism. Signs of tension in patriarchal masculinity have been identified by Mark Breitenberg, who sees early modern masculinity as ‘inherently anxious', as individuals whose identities are formed by the assumption of a privileged social position, in a social system which unequally distributes power and authority, also incorporate anxiety about its preservation. ${ }^{19}$ Patricia Crawford too asserts that men during the Interregnum, including Quakers, were anxious and fearful of the subversive implications of women's challenges to conventional distinctions between the sexes and the gendered division of labour. ${ }^{20}$ Many recent studies of the early modern period agree that masculinity was closely bound to issues of control of the household: as Elizabeth Foyster asserts, 'the key to male power in the household was thought to be sexual control of women as well as the self', ${ }^{21}$ which was combined with the expectation that men should display physical prowess to gain honour. Behaviour judged necessary to maintain both private and public honour, crucial to male power and masculine self-identity, emphasized those characteristics believed to differentiate men from women: physical strength and reason. This led to an ambiguous attitude towards violence; men were expected to show self-control, and control of the passions thought to predominate in women, but displays of strength could earn men honour, and be used to maintain physical and patriarchal control over errant members of the household. If this was lost, a man could become the victim of social censure, ${ }^{22}$ and Susan Amussen explicitly asserts in her survey of domestic violence that it was a manifestation of patriarchal power. ${ }^{23}$ As Carole Levin and Joseph P. Ward suggest, the right to use violence to correct members of the household united men in 'a common, shared responsibility' to discipline; 'a common interest in defending the theory of patriarchal authority rights' bound them. ${ }^{24}$ Violence and gender were connected in the political world but also 'in the daily practices of gender relations in the home, neighbourhood, and parish. ${ }^{25}$ Such sites of spatial belonging, where gendered, alongside other related identities such as social status and age, were enacted at local level, are of particular significance to a consideration of the implications of the Quaker peace testimony. As I will go on to argue, although territorial dominance, including that of the household, was particularly important for men who were not able to gain or maintain status by other means, which Carroll describes as 'the ubiquitous struggle of men for status and respect', for Quaker men the means of demonstrating dominance differed considerably. ${ }^{26}$ 
However, although potentially as fearful of the subversion of some gendered roles as other men, domestic violence was rejected by Friends as it was linked to disorder, particularly that of the alehouse. Their stress on an ideal of companionate marriage, with spouses sharing 'activities, goals or expectations', has been seen by Joanne Bailey, amongst others, as potentially unrepresentative, 'optimistic' at best, although it has been treated, according to Lisa Jardine, as 'a milestone in household development by early modern social historians. ${ }^{27}$ It should still be borne in mind, though, alongside Friends' rejection of violence: as Hilary Hinds notes of the early Quaker movement in particular, although it encouraged itinerant preaching, it was also 'strongly rooted in place, through household, meeting, community, and network. ${ }^{28}$ Indeed, the Quaker household was threatened most of all by those persecuting Friends; as Barry Reay outlines, in some regions ‘evidence of a man’s Quakerism was enough to have him turned... out of his home, to lose him his tenancy, even to have his vote disputed'; male Friends' role as householders was compromised by authorities who pursued them most commonly for their refusal to pay tithes. ${ }^{29}$ Both companionate marriage and the rejection of spousal abuse were predated by Puritan appeals for men to maintain domestic rule, and by inference authority elsewhere, by godly example and not by 'big looks, \& great words, \& cruel behaviour'. ${ }^{30}$ The 'choleric temper' and violence of the husband of Elizabeth Ashbridge, an early eighteenth-century Quaker, after she had refused to dance in a tavern, would have been viewed as unacceptable and disorderly by Quaker readers, but also, Foyster and Amussen's scholarship suggests, by civil members of the world. ${ }^{31}$ Ashbridge's account demonstrates the nexus which Friends recognised between the alehouse, domestic and disorderly violence; as Penn described it, 'Wives despised, and shamefully abused through the intemperance of their Husbands' ${ }^{32}$ As control of the family was analogous to control of the state, fathers were expected to provide wise leadership, sometimes by means of physical chastisement, to ensure subordinates' obedience and maintain patriarchy legitimately. ${ }^{33}$ Excessive violence, though, was seen to represent a lack of self control and, therefore, a lack of manliness. Further, excessively violent husbands threatened order in the household, and by inference, the state. ${ }^{34}$ The dishonour and shame they brought upon themselves was due to a failure to exercise reason in using strength; this could rarely be applied to Friends.

In relation to the effects of Quaker pacifism in the home, its application at a parish level are also worthy of consideration. One particular source and locus of violent masculinity in seventeenth-century society was the alehouse, and most references to Friends' rejection of the alehouse appear in their minute books, records of their 
religious and business meetings. It is apparent that this too formed part of their testimony against fighting and the use of weapons. By the early eighteenth century, young Quaker men seem to have been those most likely to be spoken to about their frequenting of alehouses, 'to the Scandall of this Blessed Truth' ${ }^{35}$ Whilst Friends seem perhaps, through some ambivalent wording, to have accepted the place of the alehouse in contemporaneous culture as the setting of many business dealings, they were not at all supportive of it as a legitimate leisure activity for their members. Indeed, alehouses were viewed across northern Europe as contributing to violence, and Friends' rejection of taverns parallels their rejection of the lifestyle of those believed to haunt them. Sailors especially were believed to be more inclined to violence, originating 'in the sociability of tavern and drink', ${ }^{36}$ as Lurting’s journal suggests. In Amsterdam, Germany and Scandinavia, alehouses were linked to a gendered culture of violence. Sailors may have felt most at home in this environment as, more than other men, they carried weapons as a matter of course, whilst violent men fleeing prosecution often joined ships. ${ }^{37}$ Many of the Friends' persecutors, who had often served in the army or local militia, participated in the same culture. ${ }^{38}$ Liliequist asserts that such violence was not simply the result of drinking bouts, but was core to ideas of manliness, and 'a means to restore or increase one's honour and manhood. ${ }^{39}$ Both Coxere and Lurting eventually abandoned their maritime occupations in favour of the bourgeois and, at the time, rural values of Quakerism, although Coxere's life pre-conversion had included such 'large liberty when ashore in drinking and sporting as the manner of seamen generally is' ${ }^{40}$

Foyster and Shepard have both commented upon the role of alehouses in seventeenth- and eighteenth-century England, where drinking 'tested the levels of self-control' and was therefore 'vital to the acquisition of honourable manhood. ${ }^{41}$ Unsurprisingly, when individuals tested their tolerance of alcohol, drunken brawling often ensued. Habitual over-drinking and loss of control could lead to loss of male credit, both socially and economically. ${ }^{42}$ Further, as Shepard argues, violence was part of male competition for status and defence of honour, and existed as a way to assert authority for all men. ${ }^{43}$ But this too was contradictory in its effects. Outside the household, Lyndal Roper has considered the disruption and disorder stemming from male drinking in early modern Germany, which led to public order problems, wife beating and civic unrest. ${ }^{44}$ Although she asserts that such behaviour was 'a serious danger to civic peace rather than a prop of patriarchy, ${ }^{45}$ she does not further consider the implication that this identifies a plurality of masculinities. The authoritarian patriarchal figure maintaining order and civility, and the rowdy alehouse brawler, could, she suggests, be the same person. ${ }^{46}$ These conflicting ideals of control and selfcontrol demonstrate the ambiguities inherent in early modern masculinity. They also show areas of tension between 
mainstream of early modern masculinity and ideals of Quaker behaviour. Quakers embraced the loss of self-control when they shook with the power of the Spirit, which gained them their derogative title, but after the Restoration they rejected violence and violent self-assertion. Penn linked excessive drinking to anger and poor business decisions, noting that ' $[t]$ he smaller the drink the clearer the head and the cooler the blood; which are great benefits in temper and business. ${ }^{47}$ This was also consonant with developments in English masculinity after 1660, when the rise of sensibility led to the development of the ideal of the loving and peaceable family man, alongside that of pure and chaste womanhood.

Thus, whilst Penn asserted that 'properly and truly speaking, men seek their wills by war rather than peace', ${ }^{48}$ many of his views on international politics could be transferred to parish level. Friends were aware that 'worldly' people favoured the use of physical force and rejected this in favour of other forms of power. Opposition to alehouse culture and the form of masculinity it represented underlines the similarity between Friends and other pious groups. Magistrates and Friends shared concerns about disorder stemming from excessive drinking and fighting; ${ }^{49}$ the 'masculine sins' of drinking, gambling and fighting were not approved of by either yet were a cornerstone of male conviviality across Europe. ${ }^{50}$ This raises the important question of how Friends and other groups rejecting alehouse culture and the accompanying violence asserted authority in the eyes of the world. If honour was associated with physical integrity, then Quakers redefined it by their courageous acceptance of martyrdom at the hands of aggressors. ${ }^{51}$ However, by rejecting the drinking of oaths, a 'symbolically charged, ${ }^{52}$ area, they risked offending others whilst rejecting a culture of drinking and violence. More importantly still, male Friends had to prove their honesty, reputation and honour without recourse to the conventional means of doing so: through violence. ${ }^{53}$

The work of the social scientist Kenneth Boulding and that of philosopher Steve Smith have been utilised in this study in order to gain a broader perspective on questions relating to Quaker masculinity and pacifism. Thus brief overviews of the scholars' works will be provided before they are applied to a specific historical period and group of people. In Three Faces of Power, the social scientist Kenneth Boulding considered the nature of social systems and asserts that 'the various forms of power’ may be divided into three major categories. Threat power, the first of these, is related to the power to destroy. Economic power is the power to produce and exchange. However, he believes, neither can achieve much without the third, integrative power, which is the most significant form of power and gives legitimacy to both economic and threat power. ${ }^{54}$ Power is often confused with the idea of force, or domination: the 
ability to get what we want. However, he rejects these limited concepts in favour of the idea of power as the potential to change. ${ }^{55}$ As Weddle suggests that seventeenth-century Friends proved ungovernable because 'to be willingly vulnerable is to be invincible', Boulding similarly comments that the freest exercise of the will may be the renunciation of power. ${ }^{56}$ For Boulding, the power of love is the most fundamental form of integrative power, ${ }^{57}$ whereas threat power 'often produces integrative weakness', 'the capacity to... alienate people ${ }^{\text {,58 }}$ or, in the case of the Friends, the capacity to lose members when other denominations seemed more appealing. Similarly, those opposing and oppressing Friends lost sympathy for themselves and gained it for the persecuted when they repeatedly threatened a people who refused to reciprocate and stressed their peaceable nature. In the case of religious organisations, Boulding claims that threat and economic power are present but not dominant; ${ }^{59}$ in the case of the Friends, arguably both, especially threat power, are present. Friends’ economic and spiritual networks were virtually inseparable, as they made business dealings within the Society and by doing so supported fellow believers and ensured that they would be dealt with honestly and openly. Friends also wielded economic power when they refused to trade with informers, and this united economic and threat power. The Quaker use of non-violent coercion is considered at length shortly, and although Boulding accepts that churches certainly use spiritual threats to maintain adherents, ${ }^{60}$ he does not consider ostracism another form of 'religious' threat power, used frequently as a disciplinary tool by early Friends.

Steve Smith's work on men and power continues many of Boulding's themes but specifically considers masculinity. Although he ostensibly deals with power, much of his work considers violence and pacifism; the manifestations of threat power are of particular importance. He asserts that from its origins Quakerism has 'preached a radical message on power and nonviolence' ${ }^{61}$ Unlike other peace churches, Friends were moved to interact with the world, at least in their testimony to 'speak truth to power', and, in conjunction with their peace testimony, -led to the development of 'an ongoing dialogue on power, peace and justice, often accompanied by profound ambivalence and soulsearching, ${ }^{62}$ However, although Smith asserts that Friends attempted to maintain their peace testimony whilst 'dealing realistically with existing power structures', ${ }^{63}$ this implies external structures with which Friends were not directly involved. However, patriarchy, one of the most fundamental ideological structures underpinning early modern society, was upheld by Friends, albeit using different methods to non-Quaker men, as their minute books and published sources reveal. Thus the division of power first identified by Boulding and developed by Smith may be identified amongst the early Friends as well as their non-Quaker contemporaries, and is inseparable from the peace 
testimony. Smith calls for an enlargement of the concept of power; rejecting claims that it is simply 'power over', or 'the ability to coerce others to act as one wishes', and arguing that it is the ability to create any perceived good. Although he does not consider Boulding's idea of exchange power, he does consider integrative and threat power in relation to religion and masculinity. Although Friends certainly used integrative power, their use of coercion when, for example, individuals were testified against 'in love', is more apparent in minute book accounts which deal with disciplinary measures. Smith’s definition of threat power includes ‘much more than blatant intimidation’; common forms are 'simple expressions of disapproval' including frowns, ridicule and ostracism which serve to enforce societal norms. ${ }^{64}$ Smith's assertion that in most societies males are assigned a larger role in using threat power, whilst females are assigned a larger role in the exercise of integrative power ${ }^{65}$ is applicable to some extent to the early Friends. Barry Levy has asserted that the 'modern family' in America originated with early Friends, who used 'modern strategies - love and voluntarism instead of shame and coercion ${ }^{66}$ and domestic matters often centred on female Friends and their use of integrative power, love and community, to cohere children and servants to the group’s beliefs.

To some extent, as Smith suggests, the type of power used was determined by gender. Men often had the final word in corporate decisions on discipline, and Women's Meetings stressed women's role as nurturers of the domestic religion, maintaining the sanctity of the home for the proper care of children and servants. Both used non-violent coercion to discipline offenders, especially over issues of dress, and identified culprits so appropriate steps could be taken. Threat power often served to protect newly defined orthodoxy, for example the post-Restoration peace testimony, with an accompanying limitation of the role of women, including Penn's objectification of Quaker women as emblems of the Primitive Church. ${ }^{67}$ Further, Friends often expected wrongdoers to admit their guilt publicly and express repentance, bolstering, in a Foucauldian reading of the events, the power of the organisation through the victim's public recognition of their misconduct. ${ }^{68}$ In most circumstances male Friends organised the public confession and imposed it upon both male and female Friends, in a gendered manifestation of authority. Pierre Bourdieu and Loïc Wacquant suggest that such behaviour may be interpreted as a form of symbolic violence; although not physically harming the individual, it 'is exercised upon a social agent with his or her complicity’ and whilst not immediately recognisable as a form of 'social game', defined by Bourdieu and Wacquant as those held crucial to society, 'such as the games of honor and war (fit for the display of masculinity, virility)', symbolic forms of violence are closely tied to the maintenance of gendered hierarchies; 'the subjective experience of relations of 
domination. ${ }^{69}$ If, as Smith asserts, the rejection of threat power is one definition of absolute pacifism ${ }^{70}$, then early Friends were not pacifist, although to reject non-violent forms of coercion and still maintain cohesion in any society would be almost impossible. This does, though, demonstrate a substantial difference of interpretation as to what pacifism is, or ideally should be: there is little evidence, if any, that seventeenth or early eighteenth-century Friends sought to abandon all forms of coercion, although they rejected violence, and were certainly aware that 'cultivating nonviolence requires extraordinary discipline, sacrifice and suffering. ${ }^{71}$ This was manifested in the self-discipline of individual Friends, but also in the disciplinary framework of local and national meetings, representing a paradox where absolute pacifism could be achieved only through corporate discipline which itself had to be enforced. Friends fell short of the ideal, using threat power for the sake of group solidarity, especially to control women, although blatant physical intimidation was rejected in favour of a form of patriarchal control which itself threatened to limit, although ultimately did not succeed in denying, women the right to preach. ${ }^{72}$ Indeed, Sarah Apetrei has demonstrated that even in the years of intermittent persecution between Restoration and Toleration, some female Friends continued to apply 'a radical anti-Calvinist critique to patriarchalism in religion'. ${ }^{73}$

Several scholars have looked beyond denominational boundaries to view pacifism, alongside violence, as a gendered experience. Feminist works of the 1980s such as Mary Daly's Gyn/Ecology reflected a radical feminist view of patriarchy as a mirror image of violence, waging 'an unceasing war against life itself. ${ }^{\text {,4 }}$ However, more recently, other commentators have denied that pacifist men cannot exist, and rejected the polarised views of men and women as innately warlike and peaceful respectively. ${ }^{75}$ Indeed, Hugh Underhill considers Friends to have been of great significance in pacifism's development, describing the peace testimony as growing from 'a withdrawal from and spiritualisation of revolutionary aggression'. ${ }^{76}$ Certainly, William Penn wrote in 1693 of the 'bloody tragedies' of war, ${ }^{77}$ and despite Meredith Weddle’s assertions to the contrary, Friends' accounts suggest that Quaker compassion for the victims of violence developed before, rather than only after, the Restoration. ${ }^{78}$ The testimony, then, is recognised by historians of pacifism as part of Friends' active engagement with the world, whilst internally, Quakers continued to discipline members along gendered lines, and their testimony was fundamentally gendered, connecting pacifism to masculinity.

In Walking in the Way of Peace, Weddle reconsiders Friends' testimony, and concludes that many other scholars have both overlooked its gradual development, ${ }^{79}$ and have anachronistically believed that as the wording of the 
testimony remained unchanged, the meaning also stayed constant for three centuries. ${ }^{80}$ It is certainly the case that although early historians of Quakerism viewed the testimony as part of Friends’ passive resistance to anything which they felt unable to do for reasons of conscience, it was represented as remaining virtually unchanged until the twentieth century. ${ }^{81}$ Weddle, then, uses King Philip's War, in Rhode Island and New England of the 1670s, as an example of Friends' differing interpretations of pacifism, and rejects assertions that Quaker pacifism developed from either faith or a political rationale alone, stressing the importance of historical context for the testimony, and rejecting the idea of 'an ideological homogeneity that did not exist. ${ }^{82}$ Quaker pacifism was not, she suggests, 'uncomplicated, homogeneous, self-evident, and unproblematical', and she reminds us of the need to consider individuals' obligations to decide what appropriate behaviour in any situation was, as well as the extent to which they were mediated in published accounts. ${ }^{83}$

Consideration of Friends' published works allows us to draw together ideals of Quaker pacifist and masculine behaviour. William Penn's overview of international issues will, then, be compared to two autobiographies of less well-known Friends, one of whom, Edward Coxere, has already been discussed by scholars of Quaker pacifism. Penn, one of the most significant Quaker figures, in both political and religious terms, of the seventeenth century, wrote several works considering the peace testimony. They actively guide the reader towards compassion for those injured, whether physically or financially, as a result of war. According to Penn, their own experience of sufferings moved Friends to dislike the use of 'outward force and corporal punishment' ${ }^{84}$ Manliness allowed Quaker men to feel pity for the victims of war; prudent Quaker men saw the waste of possessions arising from the chaos of warfare ${ }^{85}$ War, for Penn, was an uncivil waste of trade, and he countered the charge that 'effeminacy' would arise from 'disuse of the trade of soldiery': instead 'each sovereignty may introduce as temperate or severe a discipline in the education of youth as they please... This would make them men: neither women nor lions: for soldiers are the other extreme to effeminacy. ${ }^{, 86}$ He dealt with the issue of maintaining the masculinity of government in times of peace in a similar way, assuring monarchs that their authority would not be diminished by a decision not to go to war; indeed, as Christian rulers they would restore the spoiled reputation of the Church. ${ }^{87}$ Whilst individual Quakers were counselled not to fight, but to suffer; non-Quaker rulers were not expected to suffer but were told that their status would improve in the eyes of their subjects if they abandoned war.

Broadening our perspective, Friends' published autobiographical accounts, one of the richest sources for early 
Quakerism, provide additional details of individual male Quakers' decisions to become pacifist, and reveal that while for some Friends pacifism was part of their conversion, others considered themselves Quakers for some time before embracing the peace testimony. However, most journals were scrutinised by the all-male censorship committee, the Second Day Morning Meeting, which from the early 1670s decided which works were fit for publication. Views within them were therefore those acceptable to orthodox late seventeenth- and early eighteenth-century Friends, and so are very unlikely to represent the full range of opinions held in the first decades of Quakerism. ${ }^{88}$ Despite these caveats, the journals still reveal the differing ways in which Friends developed their personal interpretations of the peace testimony, and then later recounted them. Two of the most significant accounts are those of Thomas Lurting and Edward Coxere. The title of Lurting's work contrasts his previous lifestyle as a 'fighting sailor' with the postconversion 'peaceable Christian', and by implication contrasts the violent, lower class and drunken sailor with the peaceful, respectable Quakers of the early eighteenth century, ${ }^{89}$ of largely middling status, such as those told by Durham Quarterly Meeting ‘That no Ship Masters professing Truth carry Guns in their Ships. ${ }^{\text {90 }}$

Born around 1632, Lurting converted in the early 1650s, influenced by Quakers on the ship who had previously endured his beatings. ${ }^{91}$ He described the realisation that he should be pacifist as entirely personal, resulting from divine revelation, 'some scruple of conscience... although I had not heard that the Quakers refused to fight. ${ }^{\text {,92 }}$ Other Quakers on board said they would not fight again once they were home, but did not feel the same need to bear testimony against it. ${ }^{93}$ One man converted, and the captain threatened that any man refusing to fight in time of combat might be killed. ${ }^{94}$ Here, the transitory nature of worldly manhood is highlighted: the captain had been Friends' shelter from 'wicked men', but at the news of the peace testimony he became 'again our enemy'. In contrast, Lurting and his fellow Quakers prayed to receive strength 'to bear what was coming upon us'; their masculinity was based upon steadfastness, courage and faith. ${ }^{95}$ Weddle's assertion that it became impossible to oppress those who were willing to be martyred seems especially relevant to Lurting and his fellow Quakers, who felt 'the word of the Lord ran through me like fire, saying... if he will have a sacrifice, proffer it to him. ${ }^{96}$ The captain later became 'very kind and respectful to me', as threats of violence were not sufficient to control a group who believed they were 'made willing to give up to that he made known unto me, to be his will and mind' ${ }^{97}$ Whilst Weddle offers Lurting as proof that purely strategic explanations of pacifism are insufficient, as his pacifism did not defuse the threat Friends posed but rather 'exacerbated the menace he posed to others', ${ }^{98}$ perhaps instead this proof of his obedience to the Inward Light is inseparable from his self-representation as a potential martyr. Although Friends after 1660 may have 
aimed, by declaring their pacifism, to reduce the threat they were believed to pose, both before and after the Declaration they also represented themselves as ready to suffer at the hands of those willing to commit violence. Passive and stoical endurance contrasted them to their oppressors and contributed to the evolution of Quaker masculinity.

In contrast, Edward Coxere's journal, written in the late seventeenth century, remained unpublished for almost three hundred years, and therefore does not show signs of the influence of the Friends' editorial committee, and therefore offers a more complex picture of the relationship between early Quakerism and pacifism. ${ }^{99}$ Born into a maritime family, Coxere spent more than thirty years at sea and spoke several languages. ${ }^{100}$ Unlike Lurting's drawn-out experience of initial conversion to Quakerism and then to a renunciation of violence, Coxere's convincement of both came almost simultaneously, although for some time 'the Enemy of my soul' worked against his full conversion. ${ }^{101}$ After hearing the Quaker preachers Samuel Fisher and Edward Burroughs dispute with a Church of England clergyman, Coxere decided that Friends' principles were sounder than those of the cleric, and later that day experienced his 'first remarkable opening' concerning the 'fighting or killing of enemies'. He immediately visited Fisher and Burroughs to ask whether he, as a sailor, might be expected to fight. He was told to search his conscience for the answer, so his pacifism was not based ‘on other men's words, but the Lord taught me to love my enemies in his own time. ${ }^{102}$ As a result of his new beliefs, Coxere felt unable to sing hymns alongside those who had been 'swearing, cursing and lying', and became aware that 'fighting, killing, and destroying one another was of the Devil' and not God. ${ }^{103}$ Other Friends did not feel similarly moved to reject all use of weapons, and Richard Knowleman, ‘counted a Quaker', asserted that it was acceptable to fire at the enemy’s mast. Coxere, however, considered this a 'piece of deceit'. ${ }^{104}$ His rejection of such measures, and even of those practising them, fits Weddle's model of an individual acting as they thought appropriate in a given situation, although it also casts doubt on her assertion that a wide range of views on pacifism were tolerated, at least by all Quakers, in the first decades of Quakerism. Weddle, though, does consider Knowleman to have been a Friend, and, as she asserts, other individuals might have considered themselves, or others, to be Friends even if they were not pacifist. ${ }^{105}$ This complexity is, though, largely missing from accounts scrutinised, from the 1670s, by Friends' editorial body.

When considered alongside each other, Coxere and Lurting's autobiographies reveal differing interpretations of Friends' peace testimony but both men did, as individuals, finally embrace the rejection of warfare, fighting and the 
use of weapons. This may have formed part of their full spiritual conversion to Quakerism, although pacifism also had political consequences and was politically influenced, as Weddle reminds us. ${ }^{106}$ As their journals suggest, the shadow of the Civil Wars in the British Isles lay across the first generation of Friends, and their military or maritime backgrounds remained an influence even for those who had renounced violence and transferred their attention from a carnal to a spiritual plane, leaving physical combat, to the ungodly. Identifying contested forms of masculinity in the Civil War period, Diane Purkiss, citing Susan Amussen, has highlighted how, although violence against women in particular was not a norm of early modern mainstream culture, it was still part of notions of masculinity. Such ‘subcultures of transgression’ were, she believes, reflected materially in Civil War banners which depicted atrocities perpetrated by soldiers on defenceless women and were seen not only by troops but were 'public artifacts, seen by many... and often commented upon. ${ }^{107}$ However, it is also evident that for some of those actively engaged in combat, the alternative forms of masculinity offered by Quakers were attractive. In later years, though, their experiences often influenced their representation of Quaker beliefs and also their expectations of the world: 'the Lamb's War' was fought by Friends for some decades after the Restoration, when they encountered wider society: apocalyptic imagery of the Lamb and his followers at war with the Beast was employed much as it had been during the conflict, as Christopher Hill, amongst others, suggests. ${ }^{108}$ Grace Jantzen has concluded that female Friends in general rejected such language, ${ }^{109}$ and some male Friends did so also; its use, though, emphasizes the links between such language and forms of Quaker masculinity, even pacifist.

Other Friends made less explicit links to their movement's apocalyptic earlier years, although they might, like Isaac Penington, assert the Lamblike status of Friends by suggesting that like women, children and the old, Quakers were exempted from fighting, because they 'are forbidden by the love and law of God'. ${ }^{110}$ Thomas Lurting, though, stated that although he left the sea to have 'a more solid retirement, than that hurry at Sea admits of', he still noted the similarities between his former and present lives: 'For as silence is the first word of command in the martial discipline, so it is in the spiritual' ${ }^{111}$ Convinced during the Civil War, John Banks later recalled the period when 'great was the warfare and combats that I had with the Enemy of my soul', before 'peace in measure began to spring in my soul where trouble and sorrow in warfare had been. ${ }^{112}$ William Edmundson had joined the Parliamentary army and, aware of this, John Bousted commented that his previous hardness of heart had been replaced by a divine spiritual acuteness, allowing him to become 'an hammer, sharp instrument and axe in the hand of the Lord, whereby many were broken and cut to the heart'. ${ }^{113}$ The ideal masculinity represented in Quaker journals and sufferings 
incorporated martial language with a willingness to fight a spiritual war and face physical suffering with courage and bravery. Although Weddle has identified many of the ambiguities of the early peace testimony, especially apparent in colonial Friends' behaviour during King Philip’s War, the majority of published works by Quakers which used military metaphors refer to spiritual warfare. By contrasting the aggression of worldly men with their own sufferings, British Friends highlighted their passive endurance and willingness to be martyred, and it seems unlikely that many such incidents took place once they had organised the collection of sufferings testimonies and issued them to the world.

Friends' peace testimony was also manifested in more positive ways in their local communities; the 'social spheres outside the home' identified by scholars of masculinity in the long eighteenth century. ${ }^{114}$ Hannah Barker suggests, however, that this apparent development may reflect the research methods used as much as an actual addition to the sites of masculinity, and her work suggests that for many non-elite members of society, an older focus upon the home, workplace and church continued. ${ }^{115}$ Whilst this was true for many Friends, some made a very real effort made to engage formally and informally with the outside world, evidenced in sources other than genteel and urban print culture. George Coates of Cockfield in Co. Durham, for example, a yeoman and blacksmith active in his meeting from the 1670s until his death in the 1720s, was also, according to his son, 'well esteemed amongst his neighbours being often a Peacemaker'. ${ }^{116}$ Such efforts may have stemmed from a pre-Reformation tradition of mediation which after the Reformation became divided into sides competing, in John Bossy’s words, 'for the prize of representing the moral tradition. ${ }^{, 117}$ Although the church courts, he believes, made up for the absence of a rite of confession in postReformation England by using arbitration to settle local disputes, Friends certainly did not believe that recourse to law for the peaceable settlement of disagreements was acceptable. ${ }^{118}$ Like post-Reformation Catholics, whose quarrels were 'almost unheard of', Friends kept disagreements between themselves, and attempted to keep most quarrels with the outside world out of the civil and ecclesiastical courts, although neighbours and guilds helped settle disputes outside of the courts for other members of the community as well. ${ }^{119}$ The 1697 London Yearly Meeting's epistle stated that those witnessing divisions between Quakers should 'forthwith speak to, \& tenderly advise the person [sic] between whome the difference is to make a speedy End thereof'. If further discussions did not succeed, the parties were to 'each choose an Equall number of Indifferent, Impartiall \& juditious friends to here and spedily determine the same'. ${ }^{120}$ Instead of a priest, several weighty Friends would intervene. ${ }^{121}$ The technique used is similar to that outlined by Penn in his plans for a council of Imperial States; he supported government as 'the prevention or 
cure of disorder, and the means of justice, as that is of peace'. ${ }^{122}$ For Penn, writing for a non-Quaker readership, courts and parliaments existed to control disorderly 'passions and resentments'; 'men seek their wills by war rather than peace... they will hardly be brought to think of peace unless their appetites be some way gratified. ${ }^{123}$

After the Toleration Act in 1689, Friends' desire to maintain internal cohesion as a protection against 'worldly' oppressors developed into a desire to maintain internal discipline against external influences, especially those linked to 'worldly' masculinity. However, they still sought to influence outsiders positively, and were keen to retain community peace through honest business practices, and by ostracising the imprudent, whilst maintaining their membership through integrative power, which legitimated their actions as the maintenance of God's honour in the world. In this respect early eighteenth-century Quakerism mirrored moves to the figure of the 'polite gentleman' who epitomized the middling sort. ${ }^{124}$ In addition, the implications of the testimony undoubtedly differed according to gender: by the 1670s, it meant not only a rejection of violence, but the creation of an alternative means to discipline offenders and control unruly family members, who traditionally would have been physically chastised. Even if pacifism was to some degree 'forced upon them by the hostility of the outside world' ${ }^{125}$ at the Restoration, it proved fruitful when developing an identifiably Quaker masculinity.

Whilst it is apparent that Quaker manhood was different from that of most other seventeenth-century and early eighteenth-century groups, their level of patriarchal control was still substantial, despite the freedom of a significant minority of female Friends to travel and preach. This relates to what Moira Ferguson terms the 'pacifist retreat', otherwise referred to as quietism, which did not necessarily involve being silent, but listening to the spirit of God 'and urg[ing] others to hear that spirit' rather than engaging in more active manifestations of early to mid-eighteenthcentury religious revivalism. ${ }^{126}$ Ferguson's suggestion that attitudes and expectations by and of female Friends became indistinguishable from those by and of women in society as a whole is not, though, entirely borne out. However, according to dominant models of masculinity in the later seventeenth and early eighteenth centuries, it was desirable for all men to exercise the qualities of reason and strength, demonstrated through self-control and control of a household by other means than violence, and male Friends could increasingly conform to these standards. ${ }^{127}$ As Foyster has asserted, the behaviour of a wife was crucial to a man's reputation, and male Friends avoided being relegated to a 'subordinate masculinity' by upholding such ideals. ${ }^{128}$ Further, although Quakers sought only to uphold God's honour in the world, this was achieved in part by a disciplinary system which threatened ostracism for 
miscreants and in some cases defined those who had strayed but not repented as eo ipso non-Quakers. ${ }^{129}$ Through public displays of penitence expected of 'outrunners', Quakerism did not appear to be trying to usurp patriarchy: quite the contrary. Seeking, though, a balance between the extremes of worldly manhood and of its radical and egalitarian spiritual and political roots, Quakerism allowed Friends some subversion of hegemonic models of masculinity and femininity, whilst their system of discipline, albeit non-violent, was as effective as that of other groups. ${ }^{130}$ Indeed, it may perhaps be seen as part of a wider civilising process, discussed at length by scholars of early modern violence and originating in the work of Norbert Elias. Whilst that is not to suggest that Friends 'camouflage[d] disciplinary and other violence', as Vic Gatrell remarks of the civilising processes already underway in the decades studied, but rather they made public their efforts to preserve order within their membership, demonstrating male power in so doing, whilst at the same time rejecting the use of physical assault. ${ }^{131}$ Their experience, then, is better delineated using Michel Foucault's insights, and indeed those of Boulding and Smith, into 'the constitution and exercise of power', suggesting it is 'more sophisticated than [a] model which concentrates solely upon its physicality. ${ }^{, 132}$

The consideration of Quakerism in the early modern period offered here has sought to demonstrate the need in some cases to move from a relatively simplistic binary notion of 'hegemonic' and 'subversive' masculine identities. Returning to Hilary Hinds’ analysis of George Fox’s Journal, Hinds demonstrates the extent to which Fox’s selfconfidence, apparent in his Journal, lies in contrast to the anxiety of early modern masculinity. Asserting, as it has also been argued here, that Fox's confidence 'cannot simply be attributed to Fox's dissociation from contemporary paradigms of masculinity', she recognises that he, amongst other Friends, aligned himself to other models of manhood, such as Biblical figures, which 'bestowed on Fox a certain authority and gravitas.' Like other male Friends, Fox inhabited 'certain social identities culturally associated with masculinity... resilient, purposeful [and] outspoken'. ${ }^{133}$ Although these attributes were often less applicable to later, especially post-Toleration, Friends, their demonstrable masculinity, in terms of control of households and success in business, similarly worked to associate male Friends with some paradigms of early modern masculinity. However, Quaker men, Fox among them, demonstrably lacked the anxiety identified as a core of early modern masculine identity. Friends could fashion themselves into confident subjects, using Hinds’ term, by ‘combining a position of human weakness and incapacity with subjective access, through the notion of the indwelling Christ and the corporeal identification with the son, to a position of divinely originating power.' This indwelling Christ also endowed early Friends 'with immediate access to 
a source of divine authority'; a masculine ideal, Hinds suggests, which banished anxiety and installed confidence 'not by a self-sufficiency... but by a model of dependence on an omnipotent other whose beneficence in manifested in his co-extensiveness with the helpless subject. ${ }^{134}$ Bourdieu asserts, in relation to gender and symbolic violence, how bodily emotions, including anxiety, allow the dominated to unwittingly contribute to their domination. ${ }^{135}$ Quaker men especially, then, might bypass the trials of anxious worldly manhood, all too aware of social and economic as well as gendered hierarchies, and the ongoing obligation to demonstrate specific forms of gendered authority, particularly those resting upon violence, through their union with the divine.

\section{Broader conclusions about how analysis furthers our understanding of masculinity in early modern England} in terms of the dominance/ security (or otherwise) of hegemonic norms. Early Friends situated their religious determination to advocate non-resistance within strands of contemporary discourse about masculinity and were able to remain within 'male' notions of behaviour and identity by constructing their behaviour as self-control, restraint and rationality. Such ideals were coded as 'male' within seventeenth-century education and culture, and so allowed Friends to reject violence without relinquishing claims to masculine identity. Indeed, masculine identities of some non-Quakers had arguably developed so as to appear similar to Friends'; as Jennine Hurl-Eamon comments of attitudes towards domestic violence in particular, 'ideas surrounding appropriate wifely chastisement underwent a transition between the seventeenth and eighteenth centuries'. ${ }^{136}$ Carroll too notes how in London especially 'public displays of violence lost their social capital, for as commercial credit became regularized... the credit that accrued from honour was devalued', with economic success the key indicator of a man's reputation. ${ }^{137}$ Clearly this was most apparent in urban areas and amongst those of middling to higher social status, but nevertheless, it demonstrates the way in which Quakers became less unusual in their stance against violence, although their rejection of war continued to define them as outsiders. Indeed, in some cases perhaps Friends' outward deportment, including their increasing success in trade and business, influenced the behaviour of those around them, whilst their continuing rejection of worldly ideas of honour, and particularly duelling, was openly shared by some Anglican clergy by the 1690 s. ${ }^{138}$ Around the same period, and whilst contemporary commentators were noting that 'As soon as the Notions of Honour

and Shame are received among a Society, it is not difficult to make Men fight', ${ }^{139}$ Friends' methods of coercion, and continued use of military metaphors in spiritual autobiographies and accounts of sufferings, indicate that it remained difficult, even for resolute advocates of non-violent resistance, to escape the use of force entirely.

degree to which Q masc altogether different. (doesn't have to be - demonstrates how Qs developed ideas from 
${ }^{1}$ George Fox and others, A Declaration from the harmles \& innocent people of God, called Quakers, (1660), title page.

${ }^{2}$ Fox et al, 'A Declaration', p.5. Naomi Winter has considered Fox's Journal and the alternatives to hegemonic masculinity which it attempted to develop in her 'Out of the paths and steps of solid men' Literature and Theology 14 (2) (2000).

${ }^{3}$ Arise Evans, To the Most High and Mighty Prince Charles the II (1660), p.64 quoted in B. Reay, 'Popular hostility towards Quakers in mid-seventeenth-century England', Social History 5.3 (1980), p.391; T. N. Corns, 'Evans, Arise (b. c.1607, d. in or after 1660)', Oxford Dictionary of National Biography, Oxford (2004) [http://www.oxforddnb.com/view/article/8975, accessed 9 Nov 2010]

${ }^{4}$ A. Shepard, ‘From Anxious Patriarchs to Refined Gentlemen? Manhood in Britain, circa 1500-1700', Journal of British Studies 44 (2) (2005) p.290.

${ }^{5}$ K. Harvey and A. Shepard, 'What Have Historians Done with Masculinity?’ Journal of British Studies 44 (2) (2005) p.277; also Dror Wahrman's overview of elements of recent scholarship in 'Change and the Corporeal in seventeenth and eighteenth-century gender history’ Gender \& History 20 (3) (2008).

${ }^{6}$ Brod quoted in S. B. Boyd, W. M. Longwood and M. W. Muesse (eds), 'Men, Masculinity, and the Study of Religion', in Boyd, Longwood and Muesse (eds), Redeeming Men, p.xiii.

${ }^{7}$ S. Smith, 'Fear and Power in the Lives of Men', in Boyd, Longwood and Muesse (eds), Redeeming Men, p.7.

${ }^{8}$ Smith, 'Fear and Power’, p.7.

${ }^{9}$ S. B. Boyd, W. M. Longwood and M. W. Muesse, ‘Where Do We Go From Here? Some Concluding Remarks’, in Boyd, Longwood and Muesse (eds), Redeeming Men, pp 286-9.

${ }^{10}$ Boyd, Longwood and Muesse, ‘Where Do We Go From Here?’, p.290.

${ }^{11}$ P. Collins, 'On resistance: the case of $17^{\text {th }}$-century Quakers', Durham Anthropological Journal 16.2 (2009), p.14. See also H. Barbour, The Quakers in Puritan England, New Haven and London (1964).

${ }^{12}$ P. Mack, Visionary Women: Ecstatic Prophecy in Seventeenth-Century England, Berkeley, Los Angeles and London (1992).

${ }^{13}$ R. B. Shoemaker, Gender in English Society 1650-1850: The Emergence of Separate Spheres?, (1998) pp 214-5. 
${ }^{14}$ H. Hinds, ““And the Lord’s power was over all”: Calvinist anxiety, sacred confidence, and George Fox’s Journal’, ELH 75.4 (2008); M. G. Ditmore, ‘Preparation and confession: reconsidering Edmund S. Morgan’s Visible Saints’, New England Quarterly 67.2 (1994). Ditmore remarks upon Cotton Mather’s ‘third-generation filiopietistic anxiety’ (p.299, fn3) although he does not specifically link this to anxious masculinity.

${ }^{15}$ S. Davies, Unbridled Spirits - Women of the English Revolution: 1640-1660, (1998) p.223; Hinds, ““And the Lord’s power was over all”, p.862.

${ }^{16}$ See R. Watts, Gender, Power and the Unitarians in England 1760-1860, London and New York (1998), p.199 on restrictions of ‘respectability’ placed on Unitarian women, although she does not consider if this demonstrated patriarchal control.

${ }^{17}$ S. Carroll, 'Introduction', in S. Carroll (ed.), Cultures of Violence: interpersonal violence in historical perspective Basingstoke (2007), p.8.

${ }^{18}$ See for example R. T. Vann, 'Quakerism and the social structure in the Interregnum’, Past and Present 43 (1969). On Quakers, self-representation and social status see E. Bell, 'From ploughing the wilderness to hedging the vineyard - meanings and uses of husbandry among Quakers c.1650-1850’, Quaker Studies 10.2.

${ }^{19}$ M. Breitenberg, Anxious masculinity in early modern England, Cambridge (1996), pp.1-3.

${ }^{20}$ P. Crawford, Women and Religion in England, 1500-1720, (1993), p.175.

${ }^{21}$ Foyster, Manhood, p.4.

${ }^{22}$ E. Foyster, 'Male Honour', passim.

${ }^{23}$ S. D. Amussen, ““Being Stirred”’, pp70-2, 78.

${ }^{24}$ C. Levin and J. P. Ward, 'Introduction', in J. P. Ward (ed.), Violence, Politics, and gender in early modern England New York (2008), p.3.

${ }^{25}$ Levin and Ward, 'Introduction', p.7; see also J. C. Wood, 'Locating violence: the spatial production and construction of physical aggression', in K. D. Watson (ed.), Assaulting the Past: Violence and Civilization in Historical Context, Newcastle (2007), p.24.

${ }^{26}$ Carroll, 'Introduction', p.21; Martin Daly and Margo Wilson, amongst others, make this point. See Wood, 'Locating violence', p.25. 
${ }^{27}$ J. Bailey, Unquiet Lives: marriage and marriage breakdown in England, 1660-1800, Cambridge (2003), pp.6-8; L. Jardine, 'Companionate marriage versus male friendship: anxiety for the lineal family in Jacobean drama', in D. Underdown, S. D. Amussen and M. Kishlansky (eds), Political culture and cultural politics in early modern England Manchester (1995), p.234. See also T. D. Kemp, Women in the age of Shakespeare, Santa Barbara (2010), p.40 for an outline of the limitations of such ideals and the tendency for them to translate into the expected duties of women; Katherine Crawford too notes its 'highly patriarchal character’: K. Crawford, European sexualities, 1400-1800 Cambridge (2007), p.16.

${ }^{28}$ H. Hinds, ““And the Lord's power was over all”, p.855.

${ }^{29}$ B. Reay, 'Popular hostility’, p.387.

${ }^{30}$ J. Eales, 'Gender Construction in Early Modern England and the Conduct Books of William Whately (1583-1639)’, in R. N. Swanson (ed.), Gender and Christian Religion, (1998), Woodbridge, p.171.

${ }^{31}$ Elizabeth Ashbridge, Some Account of the Early Part of the Life of Elizabeth Ashbridge, Philadelphia (1807), p.36.

32 William Penn, No Cross, No Crown, (1669 edition) reproduced in H. S. Barbour (ed.), William Penn on Religion and Ethics The Emergence of Liberal Quakerism, Lampeter (1991), p.70.

${ }^{33}$ Amussen, ““Being Stirred”, p.73.

${ }^{34}$ E. Foyster, 'Male Honour, Social Control and Wife Beating in Late Stuart England', Transactions of the Royal Historical Society 6th ser, 6 (1996), p.221; A. Laurence, Women in England 1500-1760: A Social History, (1996), p.236.

${ }^{35}$ DRO, SF/Da/PM/1/1 Darlington Preparative Meeting Minutes, 8th 3mo. 1709.

${ }^{36}$ P. Spierenburg, 'Sailors and Violence in Amsterdam, 17th-18th Centuries', in M. Lappalainen and P. Hirvonen (eds), Crime and Control in Europe from the Past to the Present, Hakapaino (1999), p.123.

${ }^{37}$ Spierenburg, 'Sailors and Violence’ pp 122-3, 141; J. Liliequist, 'Violence, Honour and Manliness in Early Modern Northern Sweden', in Lappalainen and Hirvonen (eds), Crime and Control, p.183.

${ }^{38}$ DRO, SF/Du/QM/8/31 Durham Quarterly Meeting, List of Fines 1680-1685.

${ }^{39}$ Liliequist, ‘Violence, Honour and Manliness’, p.185.

${ }^{40}$ Meyerstein, A Relation, p.27.

${ }^{41}$ E. A. Foyster, Manhood in Early Modern England: Honour, Sex and Marriage, (1999), p.40. 
${ }^{42}$ A. Shepard, 'Manhood, Credit and Patriarchy in Early Modern England c.1580-1640', Past and Present 167 (2000) pp.83-4.

${ }^{43}$ Shepard, 'Manhood, Credit and Patriarchy', p.104.

${ }^{44}$ L. Roper, Holy Household, pp.107, 110-111.

${ }^{45}$ Roper, Holy Household, p.107.

${ }^{46}$ Roper, Holy Household, p.109.

${ }^{47}$ William Penn, Fruits of solitude: in reflections and maxims relating to the conduct of human life, (1857 [1693]), p.34.

${ }^{48}$ Penn, The Peace of Europe, p.5.

${ }^{49}$ D. Levine and K. Wrightson, The Making of an Industrial Society: Whickham 1560-1765, Oxford (1991), pp.307-8.

${ }^{50}$ See also Roper, Holy Household, p.111; S. D. Amussen, “"Being Stirred to Much Unquietness”: Violence and Domestic Violence in Early Modern England, Journal of Women’s History 6 (1994), p.74.

${ }^{51}$ Liliequist, 'Violence, Honour and Manliness’, p.188.

${ }^{52}$ Liliequist, 'Violence, Honour and Manliness’, p.196.

${ }^{53}$ Liliequist, 'Violence, Honour and Manliness’, p.187.

${ }^{54}$ K. E. Boulding, Three Faces of Power, (1989) pp 9-10.

${ }^{55}$ Boulding, Three Faces, pp.15-16.

${ }^{56}$ Weddle, Walking, p.25; Boulding, Three Faces, p.17.

${ }^{57}$ Boulding, Three Faces, p.110.

${ }^{58}$ Boulding, Three Faces, p.138.

${ }^{59}$ Boulding, Three Faces, p.175.

${ }^{60}$ Boulding, Three Faces, p.177.

${ }^{61}$ Smith, 'Fear and Power', p.7. 
${ }^{62}$ Smith, 'Fear and Power', p.8.

${ }^{63}$ Smith, 'Fear and Power', p.8.

${ }^{64}$ Smith, 'Fear and Power', p.8.

${ }^{65}$ Smith, 'Fear and Power', p.9.

${ }^{66}$ B. Levy, 'The Birth of the "Modern Family” in Early America', in M. Zuckerman (ed.), Friends and Neighbors, Philadelphia (1982), p.27.

${ }^{67}$ Smith, 'Fear and Power', p.11; William Penn, William Penn's Journal of his Travels in Holland and Germany, in 1677, in the service of the Gospel, (1835 [1694]), p.172, 'Penn to Elizabeth, Princess Palatinate of the Rhine 1676'.

${ }^{68}$ J. A. Sharpe and M. Foucault cited in P. Lake and M. Questier, 'Agency, Appropriation and Rhetoric under the Gallows', Past and Present 153 (1996), p.64; M. Foucault, Discipline and Punish, (1977), pp.8-9.

${ }^{69}$ P. Bourdieu and L. Wacquant, ‘Symbolic violence’ in N. Scheper-Hughes and P. Bourgois (eds), Violence in War and Peace Malden, Ma. and Oxford (2004), pp.272-3; P. Bourdieu, 'Gender and symbolic violence’ in Scheper-Hughes and Bourgois, Violence, p.339.

${ }^{70}$ Smith, 'Fear and Power', p.12.

${ }^{71}$ Smith, ‘Fear and Power', p.12.

72 e.g. Benjamin Coole, Some Brief Observations on...John Lock, (1715).

${ }^{73}$ Indeed, R. W. Connell in Masculinities (Cambridge (1995) p.189 believes Friends 'made the first public defence of equality in religion for women’. S. Apetrei ‘The universal principle of Grace’ Gender \& History 21 (1) (2009) p.132.

${ }^{74}$ Cited in B. Zanotti, 'Patriarchy: A State of War', in P. McAllister (ed.), Reweaving the Web of Life: Feminism and Nonviolence, Philadelphia (1982) pp.16-17.

${ }^{75}$ E.g. S. Perrigo, 'Feminism and Peace', in T. Woodhouse (ed.), Peacemaking in a Troubled World, New York and Oxford (1991), pp.312, 318-9; also Nicoletta Gullace’s ‘Women and war in comparative perspective’, Gender \& History 15 (1) (2003).

${ }^{76}$ Underhill, Pacifism, p.15.

${ }^{77}$ William Penn, The Peace of Europe, in W. Penn, The Peace of Europe, The Fruits of Solitude, and other writings, (1915; first edition 
1693), p.3.

${ }^{78}$ Weddle, Walking, p.53.

${ }^{79}$ Weddle, Walking pp.4, 20, 27-8.

${ }^{80}$ Weddle, Walking, p.70.

${ }^{81}$ W. C. Braithwaite, The Second Period of Quakerism, second edition, York (1979), pp.599-600.

${ }^{82}$ Weddle, Walking p.8.

${ }^{83}$ Weddle, Walking, pp.11, 44.

${ }^{84}$ William Penn, A Brief Account of the Rise and Progress of the People called Quakers, (first edition 1694), in Penn, The Peace of Europe, The Fruits of Solitude, and other writings, p.202.

${ }^{85}$ Penn, Peace of Europe, p.4.

${ }^{86}$ Penn, Peace of Europe, p.13.

${ }^{87}$ Penn, Peace of Europe, pp.14-15.

${ }^{88}$ See T. O’Malley, ““Defying the Powers and Tempering the Spirit.” A Review of Quaker Control over their Publications $1672-$ 1689', Journal of Ecclesiastical History, 33 (1) (1982)

${ }^{89}$ Thomas Lurting, The Fighting Sailor Turned Peaceable Christian, (1813; first edition 1710), title page.

${ }^{90}$ DRO, SF/Su 43 (1), 'An Abstract of Several Yearly Meeting Epistles $4^{\text {th }}$ month 1703 '.

${ }^{91}$ Lurting, Fighting Sailor, p.11.

${ }^{92}$ Lurting, Fighting Sailor, p.19.

${ }^{93}$ Weddle, Walking , p.63.

${ }^{94}$ Lurting, Fighting Sailor, p.20.

${ }^{95}$ Lurting, Fighting Sailor, p.21.

${ }^{96}$ Lurting, Fighting Sailor, p.23; Weddle, Walking, p.25. 
${ }^{97}$ Lurting, Fighting Sailor, p.24.

${ }^{98}$ Weddle, Walking, p.63.

${ }^{99}$ E. H. W. Meyerstein (ed.), A Relation of the Several Adventures By Sea...Edward Coxere, Oxford (1945). See Meyerstein’s comments, p.xii, on the 'propagandist' nature of Lurting's work compared to the more personal nature of Coxere's.

${ }^{100}$ J. Tual, ‘Guerre navale et guerre céleste: Les Aventures Maritimes d'Edward Coxere’, (2001), http://www.crlv.org/outils/encyclopedie/afficher.php?encyclopedie_id=225. (accessed 13 November 2006)

${ }^{101}$ Meyerstein, A Relation, p.87.

${ }^{102}$ Meyerstein, A Relation, pp.86-7.

${ }^{103}$ Meyerstein, A Relation, p.88.

${ }^{104}$ Meyerstein, A Relation, p.89.

${ }^{105}$ Weddle, Walking in the Way of Peace, pp4, 9, 63.

${ }^{106}$ Weddle, Walking, p.8.

${ }^{107}$ D. Purkiss Literature, gender and politics during the English Civil War Cambridge (2005) pp44-5; A. R. Young, 'Preface’ in A.

R. Young (ed.) The English Emblem Tradition: Emblematic Flag Devices of the English Civil Wars 1642-1660 Toronto (1995) p.vii.

${ }^{108}$ See T. L. Underwood, Primitivism, radicalism, and the Lamb's War Oxford (1997) p.62; C. Hill Winstanley: 'The law of freedom' and other writings Cambridge (2006 [1973]), p.17

${ }^{109}$ G. Jantzen ‘Choose life! Early Quaker women and violence in modernity’ Quaker Studies 9 (2) (2005)

${ }^{110}$ Isaac Penington, Somewhat Spoken to a Weighty Question, (1661), p.2.

${ }^{111}$ Lurting, Fighting Sailor, p.iii.

112 John Banks, The Journal of John Banks, (1712), pp.6-8.

113 'The Testimony of John Bousted’ in Banks, Journal, p.xxxv. 
${ }^{114}$ H. Barker, 'Soul, purse and family', Social History 33 (1) (2008) p.12.

${ }^{115}$ Barker, 'Soul, purse and family’, pp 12-13.

${ }^{116}$ LSF, J. J. Green, 'History of the Coates Family’, (1906), transcript.

${ }^{117}$ J. Bossy, Peace in the Post-Reformation, Cambridge (1998) p.75.

${ }^{118}$ Bossy, Peace, p.78.

${ }^{119}$ Bossy, Peace, p.83; C. Muldrew, 'The Culture of Reconciliation: Community and the Settlement of Economic Disputes in Early Modern England', The Historical Journal 39 (1996), pp.915, 918.

${ }^{120}$ DRO, SF/Da/MM 2/1, Stockton Monthly Meeting Minutes, $12^{\text {th }}$ 8mo. 1697, London Yearly Meeting Epistle, $24^{\text {th }} 3 \mathrm{mo} .1697$.

${ }^{121}$ Similarly, Bossy describes how a committee of Jesuit priests might reconcile warring members of a congregation: Peace, p.85.

${ }^{122}$ Penn, Peace of Europe, p.7.

${ }^{123}$ Penn, Peace of Europe, p.5.

${ }^{124}$ K. Harvey, ‘The History of Masculinity, circa. 1650-1800’ Journal of British Studies 44 (2) (2005) p.301.

${ }^{125}$ B. Reay, 'Quakerism and society’ in J. F. McGregor and B. Reay (eds) Radical religion in the English revolution Oxford (1984) p.153.

${ }^{126}$ M. Ferguson, Subject to others: British women writers and colonial slavery, 1670-1834 (1992) p.54; C. Gerona, Night Journeys: the power of dreams in transatlantic Quaker culture Charlottesville (2004), p.126.

${ }^{127}$ Foyster, Manhood, pp.31-2.

${ }^{128}$ Foyster, Manhood, pp.1-2.

${ }^{129}$ Foyster, Manhood, p.5; R. T. Vann, The Social Development of English Quakerism 1655-1755, Cambridge, Mass. (1969), p.132.

${ }^{130}$ Shepard, ‘From Anxious Patriarchs’ p.281.

${ }^{131}$ V. A. C. Gatrell, The Hanging Tree: execution and the English People, 1770-1868, Oxford (1994), p.590.

${ }^{132}$ D. Nash, 'Blasphemy and the anti-civilizing process', in Watson, Assaulting the Past, p.63.

${ }^{133}$ H. Hinds, ““And the Lord’s power was over all” p.843. 
${ }^{134}$ H. Hinds, ““And the Lord’s power was over all” pp.862, 866.

${ }^{135}$ P. Bourdieu, ‘Gender and symbolic violence’ in Scheper-Hughes and Bourgois, Violence, p.341.

${ }^{136}$ J. Hurl-Eamon, “'I will forgive you if the world will”: wife murder and patriarchal violence in London, 1690-1750', in J. P.

Ward (ed.), Violence, Politics, and gender in early modern England New York (2008), p.237.

${ }^{137}$ Carroll, 'Introduction’, p.23.

${ }^{138}$ D. T. Andrew, 'The code of honour and its critics', Social History 5.3 (1980), p.417.

${ }^{139}$ Bernard Mandeville, The Fable of the Bees (1728 [1714]), p.232. 